\title{
Call for papers: Special section for the 2005 Off Miyagi Prefecture Earthquake
}

We now invite you to the special section of EPS for the earthquake in the Off-shore of Miyagi Prefecture, Japan, on 16 August 2005. Any papers related to this earthquake are welcome. Since this event is closely related to previous seismic activities in this area, studies on such events in the past are also included. We shall accept only papers of the "letter" style for this special section in order to publish scientific results on these events promptly. Each letter should not exceed 6 pages in print.

Contributors to this special section should submit their papers to the editorial office of EPS, following the instructions for submission of papers as "letters" to the regular section. For details, please visit

http://www.terrapub.co.jp/journals/EPS and click on "Information for Contributors."

Please state in your cover letter that you submit your paper to "Special section for the 2005 Off Miyagi Prefecture Earthquake" We ask you to attach the list of five potential referees of your manuscript, including two or three researchers outside Japan, if possible. We welcome electric submissions to eps@terrapub.co.jp.

Upon the acceptance of each manuscript, its corresponding author will receive instructions for the final manuscript from the editorial office. We set the final deadline for this special section on 30 November 2005, but we encourage potential contributors to submit manuscripts as soon as possible in order to be included in press. This special section will preferably be published in the 2006 March issue.

For more information, please send an email message to the Editor-in-Chief of EPS (eps-ed@belinda.sci.hokudai.ac.jp). 